$\sqrt{B}$

J. bio-sci. 14: 143-145, 2006

ISSN 1023-8654

-Short Communication

\title{
DETERMINATION OF AGE AND GROWTH OF CATLA CATLA (HAM.) FROM OPERCULAR BONES
}

\author{
A Nargis \\ BCSIR Laboratories, Rajshahi, Bangladesh
}

Powel (1981) mentions that the validity of any skeletal methods for the study of growth depends in the occurrence of isometric growth between skeletal structure and body length of fish. The determination of age and growth of fish from opercular bones is well established in fishes of temperate waters and has been found to be more satisfactory than other methods e.g. from scales, vertebrae, spines, or hard parts (Le Cren 1947, Frost and Kipling 1959, Shafi and Maitland 1971, Mann 1973). The present study deals with the role of opercular bones of $C$. catla in determining the age and growth of the species.

Opercular bones were collected from 194 specimens of $C$. catla ranging from $21 \mathrm{~cm}$ to $80 \mathrm{~cm}$ in total length. The fishes were collected from the pond of BCSIR Laboratories, Rajshahi. Total length of fishes were measured by means of wooden length measuring board graduated into $\mathrm{cm}$. The length of the opercular bone was taken by a small scale divided into $\mathrm{cm}$. Length and age were fitted to the Von Bertalanffy growth curve by "Ford-Walford Plot".

Treatment of opercular bones: Frost and Kipling (1959) method was applied for treatment of opercular bones. The left opercular bone was removed from each specimen with a scalpel and immediately put into hot water and cleaned easily with a cloth. The age rings on the opercular bones were visible drying. The opercular bones were numbered and stored in envelops.

The age rings on the opercular bones can be seen with nacked eye but a more reliable count of them could be made holding the opercular bone against a narrow, sharp light source in a dark room. The maximum distance between the centre of the opercular bone and its margin was taken as the length of the opercular bone.

The relationship between bone length $(Y)$ and toatl length $(X)$ of $C$. catla was established. The age groups were considered as $0_{+}$(less than one year), $1+$ (less than two years), 2+ (less than two years) and so on. The yearly increase in length for each of the age groups was found by subtracting the mean length of each agegroup from the next older age-groups.

The total length of the fish varied from 21 to $80 \mathrm{~cm}$. No complete age ring was visible in the opercular bone of $0_{+}$age group. Age ring was first visible in the fishes of $1+$ age group. In a single fish of the sample, measuring $80 \mathrm{~cm}$ in length, seven (7) complete rings were counted; which seems that in the total collection that specimen was the oldest one. Age group 2+ was the most dominant one with a total number of 64 specimens. In the opercular bone of a single fish of $80 \mathrm{~cm}$ length a total number of 7 complete age rings were the oldest specimen in the sample. This findings agrees with Shafi et al. (1977) who found mean length for a 8 years old C. catla from Kaptai lake as $12.40 \mathrm{~cm}$. They obtained no ring formed on scale after the completion of first year of life. However, this is not true for opercular bone. The formation of first annual ring on opercular bone after completion on one year of life is not related with spawning. Shafi et al. (1977) have found that the first ring on scale appears during spawning time at two years of age. 
The fish of the younger age-groups grew more rapidly in length than the older age groups (Table 1). Similar findings have also been made by Jhaingran (1959), Natarjan and Jhingran (1963), Kamal (1969) Khan and Siddiqui (1973) from other carp species. The rings on the opercular bones of younger age-groups were clearer and more easily identifiable than in the older age-groups. This agrees with the findings of Frost and Kipling (1959) and Shafi and Maitland (1971).

Table 1. Data on the age and growth of sampled specimens of Catla catla.

\begin{tabular}{|c|c|c|c|c|c|}
\hline $\begin{array}{c}\text { Age group } \\
\text { (year) }\end{array}$ & Frequency & $\begin{array}{c}\text { Average } \\
\text { length }(\mathrm{cm})\end{array}$ & $\begin{array}{c}\text { Length range } \\
(\mathrm{cm})\end{array}$ & $\begin{array}{c}\text { Growth } \\
\text { increment }(\mathrm{cm})\end{array}$ & $\begin{array}{c}\text { Growth } \\
\text { increment } \\
\text { Mean } \pm \text { SD }\end{array}$ \\
\hline $0_{+}$ & 1 & 21 & - & 21 & 21 \\
\hline $1_{+}$ & 56 & 26 & $22-30$ & 26 & $26.83 \pm 2.15$ \\
\hline $2_{+}$ & 64 & 42 & $37-44$ & 16 & $20.41 \pm 18.57$ \\
\hline $3_{+}$ & 48 & 54 & $50-58$ & 12 & $11 \pm 2.82$ \\
\hline $4_{+}$ & 19 & 63 & $62-67$ & 9 & $8 \pm 1$ \\
\hline $5_{+}$ & 3 & 70 & $70-73$ & 7 & $5.96 \pm 0.05$ \\
\hline $6_{+}$ & 2 & 76 & $75-78$ & 6 & $4.95 \pm 0.07$ \\
\hline $7_{+}$ & 1 & 80 & - & 4 & 3 \\
\hline
\end{tabular}

The regression equation of opercular ring length and total length is linear and the equation is $Y=31 \pm 34+$ $0.353 X$ (Fig 1). The significant test of relationship between the total length (TL) and opercular ring length in $\mathrm{cm}$ is $2.66(\mathrm{P}<0.01)$ with $386 \mathrm{DF}$ which shows similar agreement in the growth pattern of different ages. The co-efficient (0.97) between total length and opercular radius shows the validity of skeletal methods to the study of growth depends in the occurrence of isometric growth between skeletal structure and body lengths. The positive intercepts value of the regression e.g. 2.66 of total length versus opercular radius has further justified to be taken in the direct consideration in the computation of length-for age (Blackburn 1950, Frost and Kipling 1959, Tesch 1968), but their significantly different relation ( $t=0.063 ; D F=P<0.001)$ have indicated the use of length intercept separately for back calculation.

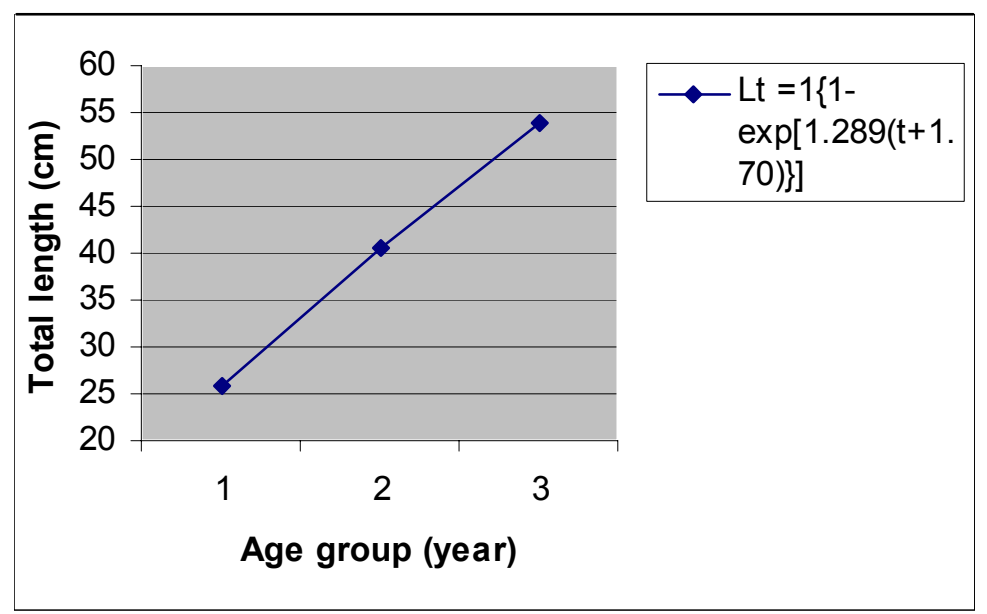

Fig 1. Von Bertalanffy growth curve for Catla catla 
For age determination in fish normally scales or vertebrae are used by the scientists or technichians in the field. The present work revealed that for cyprinid fishes, opercular rings can be used to determine the age. This method is quite easy and simple and provide more better result than the traditional technique where scales or vertebrae are used for this purpose.

\section{References}

Bagenal T B and Tesch F W (1978) Methods for assessment of Fish Production in Freshwaters. T B Bagenal (ed.), I B P Handbook No. $33^{\text {rd }}$ edn. 365 pp. Oxford Blackwell Scientific Publications.

Blackburn M (1950) A biological study of the anchovy, Engraulis anstralis (While), in Australion waters. Aust. J. Mar. Freshwater Res. 1: 3-84

Frost W E and Kipling C (1959) The determination of age and growth of Pike Esox lucius L. from scales and opercular bones. J. Anim. Ecol. 23: 314-341.

Jhingran V G (1959) Studies on the age and growth of Cirrhina mrigala (Ham) from the river Ganga. Proc. nat. Inst. Sci. India 52 (3):107-137

Kamal Y M (1969) Studies on the age and growth of Cirrhina mrigala (Ham) from the river Yamuna at Aliahabad. Proc. nat. Inst. Sci. India 35 (1): 72-92

Khan R A and Siddiqui A Q (1973) Studies on the age and growth of Rohu (Labeo rohita) from a pond and the rivers Ganga and Yamuna. Proc. Indian nat. Sci. Acad. B. Biol. Sci. 39: 582-597

Le Cren E D (1947) The determination of the age and growth of the perch (Perca fluviatilis) from the opercular bone. J. Anim. Ecol. 16: 188-204

Mann R H K (1973) Observations on the age, growth, reproduction and food of the roach Rutilus rutilus L. in two rivers in Southern England. J. Fish Biol. 5: 707-736

Nataranjan A V and Jhingran A G (1963) On the biology of Catla catla (Ham) from the river Jamuna. Proc. nat. Inst. Sci. India 29 (3): 326-355

Powel A B (1981) Annulus formation of otoliths and growth of young summer Flounder from Pambier Sound, North Carolina. Transaction of the American Fishery Society 111: 688-693

Shafi M, Quddus M A and Hoque B (1977) Studies on the age and growth of Catla catla (Ham) from the Karnaphuli reservoir and Dhaka University pond. J. Asiatic Soc. Bangladesh (Sc). 3 (1): 47- 68

Shafi M and Maitland P S (1971) The age and growth of Perch (Perca fluviatilis L.) in two Scotish rochs. J. Fish Biol. 3: 39-57

Tesch F W (1968) Age and growth. In Methods for Assessment of Fish Production in Fresh Waters ( W E Rickler ed)> IBP Hand Book No. 3, Blackwell, London. 